\title{
Intentional Informationists: Re-envisioning Information Literacy and Re-designing Instructional Programs Around Faculty Librarians' Strengths as Campus Connectors, Information Professionals, and Course Designers
}

\author{
Debra Hoffmann *, Amy Wallace \\ California State University Channel Islands, USA
}

\section{A R T I C L E I N F O}

\section{Article history:}

Received 18 September 2012

Accepted 20 June 2013

Available online $\mathrm{xxxx}$

\section{Keywords:}

Information literacy

Curricular integration

Co-curricular integration

Social justice

Critical

Thinking

\begin{abstract}
A B S T R A C T
This article adds to the recent literature that questions, and hopes to redefine, the information literacy notions and practices in academic libraries and their institutions. The authors draw on research in the area of social justice to express the need for academic libraries to explore new avenues to insure their institution's graduates are not merely competent consumers of information. The authors put forward the notion of the intentional informationist, who they define as having the contextual, reflective and informational skills to identify information opportunities, tackle complex information problems and pitfalls, and provide solutions or considerations that do not just meet her individual needs. In addition, they pose questions and detail opportunities, partnerships, and examples of curricular and co-curricular integration to engage students beyond the library, instruction sessions, a single course, or graduation requirement.
\end{abstract}

(c) 2013 Elsevier Inc. All rights reserved.

\section{BACKGROUND}

California State University, Channel Islands (CI) was the first four-year public institution to be established in Ventura County, California. This year the university will celebrate its tenth year, and offers 22 undergraduate degrees and six graduate degrees. The university's mission places students at the center of the educational experience, and provides undergraduate and graduate education that facilitates learning within and across disciplines through integrative approaches. Cl's mission emphasizes experiential and service learning, and graduates students with multicultural and international perspectives. The university community is passionate about this mission, and the university is fortunate to draw amazing students from a diverse and supportive community. The average age of our freshman class is 21, and the average age of our transfers is 27. Over $75 \%$ of our students come from the surrounding community to attend the university, and continue to work and/or care for family throughout their studies. Our students choose our university, and not the other way around. Our students have access to higher education, but access alone is not enough. We believe that it is our responsibility as librarians and faculty to provide them with an educational experience and opportunities that challenge them to reflect, engage, and act.

Although social justice is not mentioned anywhere in the university mission, elements of its many definitions are evident in planning, implementing, and assessing university goals, programs, services, and events. Many aspects of social justice are operationalized within and

\footnotetext{
* Corresponding author. Tel.: + 8054372701.

E-mail address: debra.hoffmann@csuci.edu (D. Hoffmann).
}

beyond the university. Two prime examples of this commitment are the hours that faculty from across disciplines have spent on the development of the upcoming Freedom and Justice Studies program, and the community dialogue on Social Justice and Education that the School of Education hosts annually in the university library. No matter what their background our students are asked to bring what they know, utilize past experiences, and engage beyond their personal experience, chosen discipline, and courses in order to enhance their educational experience. The campus is proud that around half of our seniors take part in some form of collaborative research or creative activity, that our students place in system-wide or discipline-based research competitions and exhibitions, and that they present on travels that combine learning and a service project in places such as New Orleans and Japan. These campus-wide expectations embody the general tenets of social justice, and are elucidated for the students in the campus mission and Cl's General Education Goals and Outcomes. The third of seven general education goals is for all graduates to be information literate. This goal has three outcomes, two of which are interpreted in line with the Association of College and Research Libraries Information Literacy Competency Standards for Higher Education: students will access needed information effectively and efficiently, and students will evaluate information and its sources critically. The third outcome, students will explain the economic, legal, social, and ethical issues surrounding the use of information, has been pondered, implemented, and assessed much differently at $\mathrm{CI}$ as a result of campus social justice discussions.

Literature on social justice no doubt informs our unique information literacy program at $\mathrm{Cl}$. Ten years of campus conversations with 
social justice at the core have made it easy to operationalize our information literacy activities and seek partnerships, but makes it very difficult for us to define social justice or even point to one social justice theorist on which we draw upon to guide us. If we had to pick one person who aligns with our information literacy program vision, values, and expectations, it would be Ira Shor. Shor writes that "critical literacy challenges the status quo in an effort to discover alternative paths for social and self-development. This kind of literacy - words, rethinking worlds, self dissenting in society - connects the political and the personal, the public and private, the global and the local, the economic and pedagogical, for inventing our lives and for promoting justice in a place of inequality" (Shor, 1999, p. 1). What is more transformative than discovering context for information presented, seeking other perspectives, delving into information creation and policy, and developing new inquires to buck the status quo? Does this not ask librarians to question how they define and teach information literacy? If information is a big part of everyday life and librarians are intimately familiar with the interests and inequalities in the information realm, shouldn't we as a profession work to integrate social critique with pedagogical techniques that help students reflect, advocate, answer, and develop information related questions and issues that impact our students' everyday lives? More importantly, what might this look like in action.

\section{PURPOSE}

Our librarians' call to action started with $\mathrm{CI}$ as a pilot campus for the ETS ICT Literacy test. This experience, and similar experiences in areas such as critical thinking and writing, soured those involved in administering the tests to their students and swayed those leading campuswide assessment efforts away from standardized tests. The results of these tests helped us to determine if we had literates and illiterates in these critical literacies based on the pre-determined and artificial outcomes of the test creators, but gave us no idea how to improve our programs or if these skills and experiences were valuable, transformative, or even memorable to our students. As a result, librarians brought the question of what it meant to be information literate to the committees on which they served, including Curriculum, General Education, and the Characteristics of Graduates Task Force. CI adopted language on information literacy in its Characteristics of Graduates in 2004, and as part of its general education goals in 2006, which included three specific outcomes for information literacy. The library faculty then created a series of workshops with composition and other faculty across disciplines to develop rubrics to assess these outcomes. We found that the rubrics developed to assess composition papers and upper-division research papers were quite effective at assessing two of the three information literacy outcomes. The library faculty worked with discipline faculty to create reflective assignments to make sense of personal and group information seeking efforts and evaluation. However, the library and discipline faculty felt unable to adequately assess the third information literacy outcome; the information literate student explains the economic, legal, social, and ethical issues surrounding the use of information (Hoffmann \& Wallace, 2008). The inability to effectively assess this outcome was incredibly frustrating since this was seen as more transformative than the other two outcomes, as it related directly to our university mission, and was viewed to be much more than a student's ability to properly attribute and cite a source in his/her paper.

This frustration led to productive dialogues. Should we be teaching undergraduates concepts and skills in order to simply function in the information age, or should we be equipping students with the theoretical framework and critical thinking skills to define, consider, solve, embrace, and champion the ethical, political, social, and cultural opportunities and dilemmas that are presented to them? We agreed that undergraduate students needed to be equipped with more than mechanics to be successful, not only as students but as informed citizens. All of this could have been seen as the daunting task described by Jacobs in her article on information literacy and reflective pedagogical praxis (Jacobs, 2008). We could have also taken the traditional route and tried to explore theories in disciplines with which we had previously partnered. However, using existing signposts is a difficult sell in a university that has only been around ten years. Instead, our librarians decided to look no further than the interdisciplinary field of library and information science to gather inspiration. Instead of saving all the interesting discussion for library and information science graduate students, why not open it up to our undergraduates, secondary, and primary school students, and communities. We have found our students can't get enough of Christine Bruce, Dan Schiller, and Karen Fischer. Furthermore, we found a need to push the envelope beyond our traditional partners in rhetoric, composition, and critical thinking by exploring partnerships with programs like business, economics, education, and media studies. Not just to maximize skills-based instruction, but to create opportunities and courses that truly explore information issues and dilemmas across disciplines.

CI librarians have always had lofty goals beyond the physical and virtual walls of the library. We wish to develop a society full of intentional informationists rather than the society of conspicuous information consumers so horrifyingly described in Johnson's The Information Diet (Johnson, 2012). The typical undergraduate has not, and probably will not, receive an introduction to information theories on the ethical, political, social, and cultural opportunities and dilemmas surrounding its creation and use. This is not to say that colleges and universities have not incorporated information literacy, media literacy, and critical thinking requirements into their undergraduate curricula. Even the most progressive offerings in this area, however, still focus on introducing concepts via other disciplines or interdisciplinary questions with a heavy emphasis on the mechanics of information seeking and the correct and incorrect uses of information. Many libraries employ standardized assessment measures to insure that basic competencies have been met before graduation. These measures may help determine if a student can use a library catalog to find a book on a particular topic, utilize social media to promote themselves to future employers, or identify bias in political advertising, but do not assess a student's ability to critically reflect on the ethical, political and social implications of information, nor do they allow students to incorporate new questions and perspectives in a meaningful way into their lives and communities. Our definition of an intentional informationist is simple: she is a person that has the contextual, reflective and informational skills to identify information opportunities, tackle complex information problems and pitfalls, and provide solutions or considerations that do not just meet her individual needs.

In his book Critical Teaching and Everyday Life, Shor concludes with a powerful call to action: "the consciousness developed in a liberatory course lays a base for transcendent change which will have to be fought for and won in multiple arenas" (Shor, 1987, p. 270). This article will introduce undergraduate courses as well as opportunities taken outside the classroom at $\mathrm{CI}$ to create occasions for reflective and critical learning in relation to our culture of information. These courses are taught by faculty from the library, communication, business, economics and education programs, and ask students to ponder key theories, opportunities and dilemmas, instead of merely meeting information seeking, evaluation and use competencies. These formal partnerships and opportunities have allowed the library to facilitate more informal means of engaging in discussions that relate to the economic, legal, and social issues surrounding the use of information. The greater hope is that our communities, policy makers, entrepreneurs, and workforces will have the contextual, reflective and informational skills to identify information opportunities and tackle complex information problems and pitfalls.

We needed to be realistic. Only limited critical thinking and reflection is going to happen in a fifty minute library session, and efforts will not be effective if they are relegated to the library. They have to be woven into the backbone of the university, its curriculum. As Shor underscores in the afterward of Social Justice Pedagogy across the Curriculum, there is an urgent need to identify common ground and 
consolidate efforts across the curriculum (Shor, 2010). We had to come to grips with the fact that some issues that need to be infused into our undergraduate curriculum do not lend themselves to neat and tidy lessons nor tests and rubrics. In fact, we found that an information literacy program focused on producing intentional informationists, would lead to more questions than answers. We also quickly realized that even the bleeding edge studies in our field continue to focus on using other discipline's theories (education, psychology, communication) to enhance content and pedagogy for one shot library instruction, library owned, stand alone or linked, credit information literacy courses, or to justify why information literacy as process should be taught in a freshman seminar and other general education courses by embedding librarians or with librarians teaching their own sections (Elmborg, 2006; Accardi, Drabinski, \& Kumbier, 2010). Unfortunately there are no tried and true models for bringing library and information science theories into other disciplines courses, or exposing users to library and information science theories via library outreach programs. As a result, we looked to partner with colleagues across disciplines to design courses to tackle the issues that stem from the fundamental questions of: what is information, do we live in an information age, and in what ways do individuals and societies interact with information on a day-to-day basis. We believe that undergraduate students can and should be introduced to theories of commodification and ownership of information, ethical uses of bio-recognition and genetic information, and convergence, as well as age-old dilemmas such as information haves and have-nots, information noise and overload, misinformation and privacy which impact them on a daily basis. Luckily, we found partners inside and outside the library to help create the spaces for our students, faculty colleagues, and the broader community to intentionally ponder issues and make yet-to-be-discovered connections and make headway towards our common goal of students to engage with the many economic, legal, and social issues surrounding the use of and access to information.

\section{LENDING DISCIPLINE EXPERTISE TO ENHANCE UNIVERSITY CURRICULA \& EXPERIENCE}

As faculty, the librarians at $\mathrm{CI}$ have been actively sought opportunities to develop and teach interdisciplinary courses and programs and co-teach existing courses. These opportunities have allowed librarians to showcase their expertise and make connections across disciplines for future partnerships. Librarians have taught sections of courses that meet the university's critical thinking requirements, and courses that meet a program's research methods. In addition, teaching faculty and librarians have considered a number of different ways to serve as a guest lecturer apart from a traditional library session that focuses on search mechanics and library services. Librarians have guest lectured to undergraduates on topics such as librarian as writer, censorship, copyright and intellectual property, community engagement, and workplace diversity. They have also spoken on campus panels and as part of university initiatives. The biggest accomplishment is that librarians have helped developed and taught more than a dozen courses. Here are three courses of which we are particularly proud (for course descriptions and additional information, see next sections).

\section{LEVEL INTERDISCIPLINARY COURSE ON INFORMATION AND COMMUNICATION}

In 2009, CI created an interdisciplinary course called Discerning Information in an Interconnected World, which is cross-listed and taught by Communication and Library program faculty. The course, which meets the university critical-thinking requirement, is designed to provide students with strategies to help them make sense of an informationsaturated world and echoes Friere's position that students should be critical examiners of their experience, questioning and interpreting their lives and educational experiences, rather than merely walking through them (Shor, 1993). Throughout the course, students critically assess information, differentiate the perspectives of information-seekers from providers and evaluate sources of knowledge through issues such as authorship, authority, information seeking behavior, gatekeeping, intellectual property and emerging information communication technologies. Goals of the course include: teaching students how to critically evaluate, decipher and assess various sources of information and apply this knowledge intentionally to their daily lives; to familiarize students with various information communication technologies and allow them to explore the practical functions, needs, benefits and limitations inherent in these technologies; and to evaluate information and its sources critically to form conclusions on information ethics, international aspects and demographic characteristics.

In this course, we ask: What is information? Does information have value? Who should be able to use or profit from it? What information should be free? What information should be protected? What is the relationship between information and technology? What technology infrastructures have been built around information? What does it mean to be information literate? Should people be? Are you? Should there be penalties for the generation of misinformation, trafficking, or unethical use of information? What is a library? What is value? In addressing these questions, students create podcasts, Wikipedia pages, Facebook entries and Twitter posts. Through this creation process, students intentionally explore the idea of "target audience" and the notions of authority and expertise-if both an "expert" in a field and they as students can create a Wikipedia entry, are they themselves now "experts"? Will the audience for that Wikipedia page be able to tell the students' entry from the expert's? Does it matter?

Students informally blog each week about open-ended information topics such as "media loyalty" (are you a Mac or PC? Do you use an iPad or will any tablet do?), the meme " 21 Things Being Killed Off by Digitalisation" (such as wristwatches, paper airline tickets, spelling, privacy), reflect if a random selection of songs on their iPod mirrors who they are, and if they could only preserve three things from their life, what would they be... and what are they doing now to preserve them. At the start of the semester, students often have a "so what" attitude toward these open-ended topics. Upon critical thinking and reflection, students often feel differently as the semester evolves. Some examples extracted from student blog posts:

With all the information that is online I am interested to see how it affects our ability to retain information. Why remember facts when you can just Google it with your smart phone? Why remember your times tables when you can calculate on a hand held device? Why read a book when you can look up the summarization of each chapter online?

I'm concerned with digitalization and the Internet and copyright on my art. I don't post a lot of my art online anymore because of all the people just taking work and posting it as their own.

Amateurs are being celebrated on the Internet, with their ideas becoming just as valid as those of the experts in the opinions of information consumers. Expert knowledge is gradually becoming less valuable in this technological world as information is democratized through various websites and this whole experience merely recon rmed to me that all serious conversations or arguments should undoubtedly take place in person. Otherwise, misunderstandings are sure to occur, and completely un ltered insults might $y$. Technology allows us to shy away from face-to-face confrontation.

Blogging about information topics related to their own experience allowed students to connect to their larger, interconnected world in an intentional, meaningful way.

Class texts range from articles and chapters from informationists in the field (such as Andrew Keen, "The Cult of the Amateur" and Luke Tredinnick, "Digital Information Culture") as well as topical discussions 
from NPR, NY Times, Wired, Vanity Fair, Salon.com etc. Students write a 7-8 page research paper on an information topic viewed through a critical lens. Paper topics have included: "Effects of Social Media on the Global Political Environment", "E-Learning: an Education Revolution", "Marketing Gone Viral" and "Effects of Text-Messaging on Literacy". Throughout the semester, each student must research something new in the field of information or ICTs, teach the topic to the class and engage students in a dialogue about the topic and its implications. By providing students access to an array of voices from the interconnected world, both scholarly and popular, instructors in this course intentionally expose students to a multitude of perspectives that students then examine through a critical eye. In doing so, students reflect on the significance and ramifications of authority, credibility, issues of big data, digital characters and digital surrogates, with the goal of being more than informed about an information topic, more than literate about a technology, but rather, intentional users and consumers of information both at the university and in their lives as well.

\section{LEVEL INTERDISCIPLINARY COURSE ON LIBRARIES AS ORGANIZATION}

Libraries in and of themselves have been credited with transforming so many people's lives regardless of a person's background or economic status. Yet, the current economic downturn has meant reduced hours and services, public company takeovers, and even closures for many libraries. There is no doubt that libraries are in demand, but they will continue to require money and resources to accomplish their missions. Those who use libraries will need to reframe the discussion away from cost cutting to bigger issues of information access, information literacy, circulation monitoring, and safe information spaces. Libraries, however, are just one aspect of a bigger discussion on information policy. The real question is who should care about libraries and information policy, and how might the questions we pose reduce the inequalities information access, use, and dissemination.

In 2007, CI created an interdisciplinary course called The Library, which is cross-listed and taught by Business, Economics, Education, and Library faculty. During the first class session, students are asked to share their most memorable library experience. Over the years, we have found that the memories are overwhelmingly positive and focus on either participating in story time at a school or public library or being let loose to browse the kids' magazines section at a public library. Students are also asked, what is the last library they used? Despite being mostly juniors and seniors in college and being asked the question while currently sitting in our library, it is almost never a college library, not even ours. For some reason, college and university libraries don't seem to count, since it is just a place you go while in school. Students are then asked what is a library, and the response has been extremely traditional, basically a building full of books. All of our students are juniors and seniors, would be categorized as digital natives, and our campus and library is less than ten years old. We have found this traditional definition then forms the basis for the inevitable value judgments. Libraries are physical structures with just a bunch of books, and nobody reads books anymore, so we should close them all. Libraries' main users are children, and I don't have any children, so I am not going there any time soon. At the end of the first session, we always know that it is a long road ahead to inform, discuss, challenge, and ponder complex dilemmas.

Outside of class, students are asked to read chapters and articles by a wide variety of researchers in the field of library and information science, current newspaper articles, and even web resources like the Temescal Tool Library in Oakland and the Biblioburro video on YouTube (Oakland Public Library, 2012; Soriano, 2007). Students visit a variety of libraries to hear guest speakers, including the University of California Doheny and Cinematic Arts Libraries, Los Angles Public Downtown Branch, local public high school and elementary school libraries, Ronald Reagan Presidential Library, Amgen library, and Western Foundation of Vertebrate Zoology Library. In addition, students are asked to visit two libraries on their own and complete an assignment that considers mission, finances, and users in order to make sense of services and collections. In-class discussions are focused on topics such as access to whom and for what; preservation challenges, public record; historical narrative; user needs, services, and physical and virtual spaces; teaching, learning, and libraries; costs, benefits, finances, notion of free, and politics; private, public, non-profit, and commercial libraries; technology, change, and the library as a workplace, and school libraries, textbooks, reading programs, and learning.

To gauge reflection, application, and creativity on the course content, students are required to keep weekly reflective journals that connect readings, visits and discussions and write two library analysis papers. The course culminates in an interdisciplinary group project, which includes written and oral components. The project must identify a library issue or dilemma, provide the class with background on why we should care, transform it or solve it; provide an implementation plan that includes a way to market the plan and assess results within the library environment. Students have looked at the issues surrounding the reading program Accelerated Reader in school libraries, employed regression models from Economics to assess services in public libraries, presented a solution on textbook affordability that pulled on library collections, and pondered ways to extend career services and develop information literacy skills based on needs assessment data. Based on student reflections, we have found certain things consistently resonate more than others. Those things are: standing in the main lobby for the Los Angeles Public Library-Downtown Branch when the doors open in the morning; watching the kids crowd around Luis Soriano when he comes to town with his Biblioburro; the amount of money that libraries spend on collections and services but how little if any cost is passed on to the user; and the extent to which libraries are already employing current and emerging technologies.

\section{CAPSTONE COURSE FOR FUTURE TEACHERS}

The school district closest to our university no longer requires credentialed librarians at their elementary schools. In addition, some 85 credentialed teacher-librarians got layoff notices [in Los Angeles Unified School District]. If state education cuts end up being as bad as most think likely, their only chance to keep a paycheck is to prove that they're qualified to be transferred into classroom teaching jobs (Tobar, 2011). This trend is upsetting by itself, but coupled with the fact that college students cannot define what it means to be information literate, covey the usefulness of the information literacy skills acquired, realize their limitations and know when more skills are needed, or articulate the value for teaching these skills to their children, colleagues, or friends is alarming. Librarians at $\mathrm{Cl}$ responded to this issue by partnering with CI's School of Education to offer a senior capstone course on information literacy for the Liberal Studies Program. Most students were planning on going into a teacher credential program, but some were interested in librarianship and law enforcement. We saw this class as an opportunity for students to put information literacy knowledge into action: a second grade teacher coming to the school librarian or media teacher to partner on creating a lesson, or a marketing executive setting up a training session after realizing that information skills could help colleagues complete a research project. The course was at the undergraduate level, but similar courses and workshops have been woven into post-baccalaureate teacher education programs and in the workplace. Earp's (2009) recent article discusses the success of a grant to integrate information literacy into teacher education and Griffin and Ramachandran's (2010) article showcased their efforts to help pre-service teachers connect information literacy with California science curriculum standards. Sokoloff (2012) builds on the exciting research from Australia and Scotland by examining the synergies and divergences between academic and workplace information literacy in the United States. The ultimate goal for this group of intentional informationists was to articulate their own definition of information 
literacy, value its parts and teaching, place it within the continuum of lifelong learning, and be able to pass on what they have learned to others.

On the first day of class before any lecture or readings, students were asked to create two concept maps that addressed the questions; what is information literacy and what does it mean for a person to be information literate? The students were also asked to write a reflection that addressed the following questions: what do you expect to learn in this class; what do you expect to experience in this class; what is information literacy; what does it mean for a person to be information literate; is there value in being information literate; and do you believe that you are information literate. Course readings and class discussions centered on information literacy definitions, standards, connections to other skills and literacies, and connections to other disciplines. These came from a variety of different perspectives from both inside and outside the United States, including readings from William Badke, Christine Bruce, Michael Eisenberg, Annemaree Lloyd, Paul Sturges \& Almuth Gastinger, and Dane Ward. The course instructor emphasized that there is no one way of defining and teaching information literacy, and creating a meaningful activity or experience for students depends on a variety of factors, the most important of which is what the student brings to the table and what is relevant to their everyday lives. Students were asked to observe librarians and their students and information professionals and their users in action. Students were also asked to seek their own information on topics of interest; including searching the world wide web for political information, constructivist learning, the relationship between information literacy and critical thinking, value of information skills in the workplace, and censorship. During this process the students were asked to reflect, revise and share their concept maps.

The final projects were more powerful than the professor had imagined. The project required a 10-12 page essay on information literacy, which asked them to provide their definition of information literacy along with any concepts and standards, how their definition related to the other skills, disciplines, and literacies discussed in class, their definition of an information literate person (with attention to how they would know it if they saw it), opinions on when and where should information literacy be taught, and which information literacy skill, concept, or experience would they teach someone else. The project also required five information literacy lesson plans on concepts and skills that they wished to teach to someone else, notes and discussions with their fieldwork mentor, and annotated bibliography. The information literacy essays showed passion and ownership for the definitions created, and were not merely cut and paste quotes from an organization or person. Essays and lesson plans not only reflected course readings and discussions, but fieldwork observations and outside research. Lesson plans addressed purpose, objectives and connections to information literacy and grade standards, classroom organization, needed equipment and materials, instructional sequences, and assessment. Over the years, lessons have included teaching second graders to formulate questions and ponder needed information, sixth graders to use organization and search features of an electronic textbook, eighth graders to evaluate a website found on a topic, police officers how to search for and evaluate emerging information communication technologies for purchase, and co-workers how to validate information found on the web for a project. Furthermore, these lessons were not only reserved for the student portfolio, or for that all important grade. In most instances, the Information Literacy Capstone students actually taught the lessons they created to $\mathrm{K}-12$ students and/or co-workers.

\section{USING LIBRARY AND INFORMATION SCIENCE THEORIES TO MAKE} LIBRARY OUTREACH MORE THAN AWARENESS AND PUBLICITY

We believe the first big leap for librarians is to consider themselves as full partners in curriculum development, and not just there to inform collection development and promote library collections and services. Colleagues in our university library system have done the same. Reza
Peigahi has been actively involved in General Education reform at CSU Sacramento and Catherine Haras has contributed to faculty development as Acting Director for the Center for Effective Teaching and Learning at CSU Los Angeles. However, we understand that not all librarians have an opportunity to co-create and co-instruct credit bearing classes with content that allows students to ponder the democratizing and social justice elements inherent in information literacy as Jacobs (2008) article so aptly describes. We would argue, however, that one does not need a library session, series of classes, or an entire course to effectively incorporate reflective pedagogical practice. In addition, all librarians, not just teaching librarians, will need to fully embrace Lee's (2000, p. 9) argument, that pedagogy is constituted by reflection and action that takes place in multiple and sometimes simultaneous spheres of action in the classroom and outside it, presented in Jacobs (2008). For our library, the planning for this type of teaching is not situated in our information literacy program, but instead in our outreach program. We have always considered pedagogy when planning and partnering on outreach activities. While outreach librarians can help identify opportunities and partnerships, everyone in the library needs to consider what we might want students to ponder. Some of the most interesting discussions and dilemmas in our field right now do not make their way into the literature read or conferences attended by information literary, instruction, outreach, or public services librarians; librarians talking to other staff and faculty across campus about these discussions and dilemmas will no doubt help to frame potential reflections theoretically and practically.

The intentional informationist also needs a place to explore, reflect, practice, and dialogue beyond the confines of a course and classroom. Courses are high stakes with tests, papers, and grades. Information is seen as necessary to accomplish tasks and products, and as a result students are not always focused on critical thinking and reflection on information itself. The first step might be getting your students thinking about information and its many facets. $\mathrm{Cl}$ librarians have found success creating a space outside our information literacy program by considering pedagogy when planning and partnering on-campus outreach activities. Our outreach librarian, Elnora Tayag, created a monthly Salon de Literatea to bring faculty and students together to discuss research and topics of interest. The gatherings were held in the library with tea, snacks, and no set agenda. An informal get together such as this might be the place to pose some questions or ponder current events such as information, privacy, or Google's decision to share information across its holdings to allow its advertisers to better market to its users, digital characters and surrogates, or fair labor practices. This kind of reflection can even be encouraged among your non-matriculated students. Our library has a strong connection with the Osher Lifelong Learning Institute at $\mathrm{CI}$ that holds courses on campus and in sites around Ventura County. They offer multi-week and one-shot courses on topics from banned books to European and American Art from 1900 to 1960. The library has also brought together our students and Osher students for one-time events, such as watching the Obama inauguration followed by a discussion on the history, symbols, and rhetoric of presidential inaugural speeches. One future event might be bringing people together to talk about privacy, health information, treatment, and insurance coverage. Another might be a short course that centers on Dan Schlliler's work on the commodification of information. Still another might incorporate big data, marketing, facial recognition technologies, GPS, and RFID. The ultimate measure of success would be if participants start bringing their own information related topics to pose to the group.

The second step might be to get your students reading and reflecting on information and its complexities. Librarians have made suggestions for Cl's One Campus, One Book program. Book suggestions have included The Social life of Information, Emanuel Goldberg and His Knowledge Machine: Information, Invention, and Political Forces, The Information Diet: a Case for Conscious Consumption, Immortal Life of Henrietta Lack, and Information: A History, A Theory, A Flood, and could spark all sorts of conversations on information. Librarians buy works of fiction that revolve around information for the 
library's popular collection, such as The Informationist, The Girl with the Dragon Tattoo, and Carte Blanche. The library also has a popular movie collection that includes The Social Network, Inception, Avatar, Minority Report, Gamer and Timer, just to name a few. The action movie Gamer, for example, looks at questions of digital surrogacy taken to the extreme, and the comedy Timer explores the gray areas around information, lack of information, bias, and emotion. The works might lend themselves to an information themed book group or movie club.

The third step might be to infuse information literacy where it might be least expected. Our library has also built special collections around student interest in local people, issues, and history by actively seeking materials from our community at-large. Therefore, it has been important to us to facilitate dialogues about personal information management, information ownership, obstacles to preservation and metadata, resource sharing, and the power of folksonomies.

\section{NEXT STEPS}

The CI Library will continue to provide a comprehensive skills-based information literacy program for its students. The library will also continue to be active in the development of courses that push the standard boundaries of information literacy in hopes of shifting the emphasis from literate to informed, from passive receptors of information to intentional users and consumers of information. Two new courses that are cross-listed with the library are scheduled to be offered this fall semester. One course is Literacies in a Changing World, which was developed by a librarian, education professor, and history professor. The course will meet multiple general education requirements, and be incorporated into the second year experience. The course will explore literacy from a multiple-literacies perspective, its history and its relationship to global societies, social change and ultimately social justice. The course hopes to broaden students' understanding of literacy and what it means in today's multicultural world, both for the student and for others in the global and local community. The second is a course that centers on learning about politics in California through primary documents. This course will have students delve into hundreds of boxes of archives, consider the individual and collective significance of documents to help better understand political concepts and contextualize issues, and organize documents for use and re-use by others.

The $\mathrm{Cl}$ librarians will continue to seek inspiration from eclectic and unlikely sources. Here are a few things that have captured our interest lately: the recent Knight Foundation Report calling for society to employ more active language to move students along the information continuum (Knight Foundation, 2001). Students would go from "aware" to "motivated" to "experimenting" to "committed" to "engaged" in order to navigate their information-saturated world for life. How might we develop or observe a student who is experimenting with information? Second, the United States Supreme Court's unanimous decision that required a warrant for law enforcement to place a GPS tracking device on a vehicle (United States v. Jones 565 U. S. Online. The Supreme Court, 2012). Although the decision was unanimous, the case resulted in a majority and two concurring opinions that disagreed on the scope and impact of this decision. Even more interesting in this age of partisan politics, these opinions did not neatly map to party affiliation or personal backgrounds. What do these opinions say about the myriad of unresolved issues in the area of privacy rights, personal information, and safety and security in our communities? Third, the work being done at the intersection between information and psychology questions the basic assumption that it is possible to understand one's information landscape and effectively seek and evaluate information. Lowry et al.'s (2012) article discusses the impact of creating better privacy assurances for websites, but is this focus on assurance rather than actually making things more private the best answer for society. Outside our field, social psychologists have published studies that examine the impact of cognitive dissonance on information seeking and selection of information from the media to political campaigns. Fourth, are the studies that are using what we know about information behavior to build more effective systems that mine your personal data, identify and filter unceasing newly uploaded pornographic content, locate personal insults on social media sites, and monitor plagiarism cases in scientific publications (Ortiz-Cordova \& Jansen, 2012; Lee \& Chen, 2012; Sood \& Churchill, 2012; Alzahrani, Palade, Salim, \& Abraham, 2012). Although some may appear to be worthy efforts, it seems wise to ponder how else these information systems might be employed to restrict a person's rights.

We challenge fellow librarians to reflect on how they can work within and beyond their colleges and universities to produce intentional informationists. Think about all the potential reflective action that could be taken by a person who possesses the contextual, reflective and informational skills to identify information opportunities, tackle complex information problems and pitfalls, and provide solutions or considerations that do not just meet individual needs. Where are you developing intentional informationists in your library?

\section{APPENDIX A}

http://faculty.csuci.edu/debra.hoffmann/.

\section{REFERENCES}

Accardi, M. T., Drabinski, E., \& Kumbier, A. (Eds.). (2010). Critical library instruction: Theories and methods. Duluth: Library Juice Press.

Alzahrani, S., Palade, V., Salim, N., \& Abraham, A. (2012). Using structural information and citation evidence to detect significant plagiarism cases in scientific publications. Journal of the American Society for Information Science and Technology, 63(2), 286-312.

Earp, V. (2009). Integrating information literacy into teacher educcation: A successful grant project. Behavioral \& Social Sciences Librarian, 28(4), 166-178.

Elmborg, J. (2006). Critical information literacy: Implications for instructional practice. The Journal of Academic Librarianship, 32(2), 192-199.

Griffin, K., \& Ramachandran, H. (2010). Science education and information literacy: A grass-roots effort to support science literacy in schools. Science \& Technology Libraries, 29(4), 325-349.

Hoffmann, D. \& Wallace, A. (2008). Information competence assessment using first year and upper division writing samples. In S. Hiller, K. Justh, M. Kyrillidou, \& J. Self (Eds.), Proceedings of the 2008 library assessment conference: building effective, sustainable, practical assessment (pp. 477-484). Seattle: Association of Research Libraries.

Jacobs, H. (2008). Information literacy and reflective pedagogical praxis. The Journal of Academic Librarianship, 34(3), 256-262.

Johnson, C. (2012). The information diet: A case for conscious consumption. Sebastopol: O'Reilly Media, Inc.

Knight Foundation (2001). Knight community information challenge: 2011 evaluation findings. Online. Available http://www.knightfoundation.org/media/uploads/publication_ pdfs/KCIC_2011_Evaluation_Findings.pdf

Lee, A. (2000). Composing critical pedagogies: Teaching writing as revision. Urbana, IL: National council of Teachers of English.

Lee, L., \& Chen, H. (2012). Mining search intents for collaborative cyberporn filtering. Journal of the American Society for Information Science and Technology, 63(2), 366-376.

Lowry, P., Moody, G., Vance, A. Jensen, M. \& Wells, T. (2012). Using and elaboration likelihood approach to better understand the persuasiveness of website privacy assurance cues for online consumers. Journal of the American Society for Information Science and Technology, 63(4), 755-766.

Oakland Public Library (2012). Temescal tool library. Online. Available http://www. oaklandlibrary.org/Branches/temtll.htm

Ortiz-Cordova, A., \& Jansen, B. (2012). Classifying web search queries to identify high revenue generating customers. Journal of the American Society for Information Science and Technology, 63(7), 1426-1441.

Shor, I. (1987). Critical teaching and everyday life. Chicago: University of Chicago Press.

Shor, I. (1993). Education in politics: Paulo Freire's critical pedagogy. In P. MacLaren, \& P. Leonard (Eds.), Paulo Freire: A critical encounter. New York: Routledge.

Shor, I. (1999). What is critical literacy? In I. Shor, \& C. Pari (Eds.), Critical literacy in action: Writing words, changing words. Portsmouth: Boyton/Cook Publishers Inc.

Shor, I. (2010). Afterword. In T. Chapman, \& N. Hobbel (Eds.), Social justice pedagogy across the curriculum: The practice of freedom. New York: Routledge.

Sokoloff, J. (2012). Information literacy in the workplace: Employer expectations. Journal of Business \& Finance Librarianship, 17(7), 1-17.

Sood, S., \& Churchill, E. (2012). Automatic identification of personal insults on social news sites. Journal of the American Society for Information Science and Technology, 63(2), 70-285.

Soriano, L. (2007). Biblioburro. Online. YouTube. Available http://youtu.be/wuTswmx9TQU

Tobar, H. (2011). The disgraceful interrogation of L.A. school librarians. Online. The Los Angeles Times Available http://articles.latimes.com/2011/may/13/local/la-me-0513tobar-20110513

United States v. Jones 565 U. S. Online. The Supreme Court (2012). http://supremecourt.gov/ opinions/11pdf/10-1259.pdf 